\title{
JC Virus Antibody Measurement
}

National Cancer Institute

\section{Source}

National Cancer Institute. JC Virus Antibody Measurement. NCI Thesaurus. Code

C112326.

The determination of the amount of JC Virus antibody present in a sample. 